3. E. B. Thompson and M. E. Lippman, Metabolism 23, 159 (1974).

4. J. P. Binette and K. Schmid, Arth. and Rheumat. 8, 14 (1965).

5. J. S. Lowe and E. H. Turner, Biochem. Pharmac. 22, 2069 (1973).

6. J. S. Lowe, Biochem. Pharmac. 13, 633 (1964).

7. E. Milgrom and E. Baulieu, Biochim. biophys. Acta, 194, $602(1969)$.

8. G. A. Bray, Analyt. Biochem. 1, 279 (1960).
9. A. G. Gornall, C. J. Bardawill and M. M. David, J. biol. Chem. 177, 751 (1949).

10. A. J. Collins and D. A. Lewis, Biochem. Pharmac. 20, 251 (1970).

11. R. R. Gala and U. Westphal, Endocrinology 77, 841 (1965).

12. R. H. Persellin, G. W. Kittinger and J. W. Kendall, Am. J. Physiol. 222, 1545 (1972)

13. P. S. Hench, E. C. Kendall, C. H. Slocumb and H. F. Polley, Ann. rheum. Dis. 8, 97 (1949).

\title{
Decreased rat brain acetylcholine utilization after heroin and cross tolerance to $l$-methadone*
}

(Received 31 July 1974; accepted 4 Octoher 1974)

It is well known that morphine and related narcotic analgesics decrease acetylcholine $(\mathrm{ACh})$ release from the peripheral and central nervous system [1-4]. In addition, brain $\mathrm{ACh}$ utilization and turnover are decreased $[5,6]$. ACh utilization is an indirect measure of ACh turnover, since the compound used to inhibit its synthesis does not have an immediate effect. When the synthesis of $\mathrm{ACh}$ is reduced by hemicholinium-3 (HC-3) or acetylseco HC-3, drugs can be given at various times in order to determine if $A C h$ utilization has been altered. A drug that alters brain $\mathrm{ACh}$ to a level below or above that found with an $\mathrm{ACh}$ depletor alone is interpreted to increase or decrease ACh utilization respectively. Narcotic anaigesics, including $l$-methadone, antagonize brain $\mathrm{ACh}$ reduction produced by the $\mathrm{ACh}$ anti-synthesis agents like $\mathrm{HC}-3$ and acetylseco $\mathrm{HC}-3$ [5]. The present study summarizes results which indicate that acute adrninistration of lervin causes a decrease in brain $\mathrm{ACl}_{1} \mathrm{uli}$ lization. Rapid partial cross tolerance to this action of heroin can be demonstrated to $l$-methadone given twice daily for only 4 days.

Male Holtzman rats, $20-24$ days old $(60-80 \mathrm{~g})$, were housed 10-13/cage. They were on a 7:00 a.m. to 12:00 p.m.

* Supported by a grant from the Domino family and USPHS DA 00830. light and 12:00 p.m. to 7:00 a.m. dark cycle. They were given food and water $a d$ lib. All drug doses were calculated as base. Two different treatments were used on various groups of animals. Une group received $2.5 \mathrm{mg} / \mathrm{kg}$ of $/$-methadone i.p. for 2 days b.i.d., $12 \mathrm{hr}$ apart and then $5 \mathrm{mg} / \mathrm{kg}$ for the remaining 2 days on the same dose schedule. The other group of rats was given $09 \% \mathrm{NaCl}$ in a volume equivalent to those receiving $l$-methadone b.i.d. for 4 days. This dose schedule of $l$-methadone allowed the young rats to gain weight at the same rate as the $0.9 \% \mathrm{NaCl}$ controls. About 5-10 per cent of the animals given methadone died. On day 5 , the rats were given simultaneously heroin i.p. and $5 \mu \mathrm{g}$ acetylseco $\mathrm{HC}-3(0.25 \mu \mathrm{g} / \mu \mathrm{l})$ intraventricularly (ivt.) under diethyl ether anesthesia $30 \mathrm{~min}$ prior to being guillotined. Acetylseco $\mathrm{HC}-3$ is especially useful because it is a choline acetyltransferase inhibitor that causes significant decreases in biain ACh compatible with survival [7].

The brain minus the cerebellum was rapidly removed, weighed and homogenized in acetonitrile to which 25 nmoles proprionylcholine ( $\mathrm{PCh}$ ) iodide had been added as internal standard. The samples were prepared for pyrolysis gas chromatography (GC) by the method of Szilagyi $e t$ al. [8]. However, the GC conditions were slightly altered for convenience. Stainless steel columns, $8 \mathrm{ft}$ in length, packed with Chromasorb W (HMDS) coated with $20 \%$ Carbowax 6000 , were used. Column temperature was $145^{\circ}$. flame ioni-

Table 1. Effects of heroin on brain acetylcholine utilization in rats treated with $0.9 \% \mathrm{NaCl}$ or 1 -methadone

\begin{tabular}{|c|c|c|c|c|c|}
\hline Treatment & $N$ & $\begin{array}{c}0.9 \% \mathrm{NaCl} \\
\text { Mean } \pm \text { S.E. ACh } \\
\text { (nmoles } / \mathrm{g})\end{array}$ & $N$ & $\begin{array}{c}\text { l-Methadone } \\
\text { Mean } \pm \text { S.E. ACh } \\
(\text { nmoles } / g)\end{array}$ & $\mathbf{P}$ value* \\
\hline Controls & 11 & $23 \cdot 9 \pm 0 \cdot 7$ & & & \\
\hline Acetylseco HC-3 $(5 \mu \mathrm{g})$ & 9 & $11 \cdot 1 \pm 0.5$ & & & $<0.001$ \\
\hline \multicolumn{6}{|l|}{$\begin{array}{c}\text { Acetylseco HC-3 }(5 \mu \mathrm{g}) \\
+ \text { heroin }(\mathrm{mg} / \mathrm{kg})\end{array}$} \\
\hline $0 \cdot 1$ & 8 & $12 \cdot 9 \pm 1 \cdot 1$ & & & \\
\hline 0.32 & 9 & $15.6 \pm 1.0$ & 9 & $12 \cdot 3 \pm 0.8$ & $<0.01$ \\
\hline 0.56 & 10 & $17.9 \pm 0.8$ & & & \\
\hline 1.0 & 9 & $23 \cdot 8 \pm 1 \cdot 5$ & 9 & $14.7 \pm 0.9$ & $<0.001$ \\
\hline $3 \cdot 2$ & 9 & $17 \cdot 1 \pm 1 \cdot 2$ & 9 & $18 \cdot 4 \pm 1 \cdot 1$ & NS \\
\hline $10 \cdot 0$ & & & 13 & $15 \cdot 1 \pm 0.4$ & \\
\hline
\end{tabular}

* Group comparison " $t$ " in which the effects of acetylseco $\mathrm{HC}-3$ alone were compared to controls, or the $0.9 \% \mathrm{NaCl}$ and $l$-methadone-treated groups were compared. Heroin plus acetylseco $\mathrm{HC}-3$ was given to rats treated 4 days with $0.9 \%$ $\mathrm{NaCl}$ or $l$-methadone. $\mathrm{NS}=$ not significant. 
zation detector, $200^{\circ}, \mathrm{N}_{2}$ was $75 \mathrm{ml} / \mathrm{min}$, air, $1.51 / \mathrm{min}$, and $\mathrm{H}_{2}$ flow adjusted to given maximum response. Peak areas were calculated by determining the height $\times$ width at $\frac{1}{2}$ the height. The retention times for the demethylated $\mathrm{ACh}$ and PCh were 4.5 and $6.0 \mathrm{~min}$ respectively.

As noted in Table 1, $0.9 \%$ NaCl-treated rats given increasing doses of heroin and $5 \mu \mathrm{g}$ acetylseco $\mathrm{HC}-3$ showed an increase toward control levels in mean brain $\mathrm{ACh}$ compared to rats that received only acetylseco HC-3. This effect of heroin was maximal at $1 \mathrm{mg} / \mathrm{kg}$ and then declined. With $3.2 \mathrm{mg} / \mathrm{kg}$ of heroin, the rats exhibited a catatonic syndrome and aversion to touch. A dose of $10 \mathrm{mg} / \mathrm{kg}$ of heroin plus $5 \mu \mathrm{g}$ acetylseco $\mathrm{HC}-3$ was 95 per cent lethal. In rats treated for four days with $l$-methadone, heroin caused less of an increase in brain $\mathrm{ACh}$ compared to the $0.9 \% \mathrm{NaCl}$-treated rats. The maximal increase was found with $3.2 \mathrm{mg} / \mathrm{kg}$ of heroin plus $5 \mu \mathrm{g}$ acetylseco $\mathrm{HC}-3$. A dose of $10 \mathrm{mg} / \mathrm{kg}$ of heroin plus $5 \mu \mathrm{g}$ acetylseco HC-3 was not lethal in the $l$-methadone-treated animals. Rats at this dose exhibited rigidity and aversion to touch, as the $0.9 \% \mathrm{NaCl}$-treated animals given heroin did. They did not appear sedated.

It can be seen from the data in Table 1 that $l$-methadonetreated rats show a dose-effect curve to heroin which is shifted to the right. The $l$-methadone-treated rats exhibited a decreased ability to prevent the depletion of brain $\mathrm{ACh}$ after heroin and ivt. acetylseco HC-3. Hence, one can conclude that cross tolerance is present. Our previous studies indicate that rats receiving morphine for only $1-4$ days show a similar lack of response to morphine [5], indicating rapid tolerance to this narcotic effect. Of interest is the fact that cross tolerance is marked to doses of heroin below $1.0 \mathrm{mg} /$ $\mathrm{kg}$, in contrast to the effects of doses of heroin above $3.2 \mathrm{mg} /$ $\mathrm{kg}$. However, since $l$-methadone was given for only 4 days, this is not surprising. Longer treatment periods with $l$-methadone should also be studied to determine if cross tolerance is more marked. The inverted "V"-shaped dose-effect curve of heroin plus acetylseco $\mathrm{HC}-3$ on brain ACh utilization resembles our previous findings with narcotic agonists such as codeine and meperidine [5]. Inasmuch as these agonists are more "stimulant", it may be that this phenomenon is related to "stimulation" occurring with the larger doses.

The present results are interpreted to indicate "cross tolerance" on the assumption that methadone does not change the shape of the dose-response curve via a mechanism other than cross tolerance. This assumption seems valid in view of the lack of data to the contrary. We have previously shown that the effects of heroin on brain $\mathrm{ACh}$ are similar to those of morphine, methadone and related narcotic agonists [5].

The finding of cross tolerance between $l$-methadone and heroin is further evidence that reduction of brain $\mathrm{ACh}$ utilization and turnover is a specific agonist action. probably related to the depressant effects of narcotics.

Department of Pharmacology,

University of Michigan,

EDWARD F. DOMINO Ann Arbor, Mich. 48104, U.S.A.

ANN E. WILSON

REFERENCES

1. W. Schaumann, Br. J. Pharmac. Chemother. 12, 41 (1957).

2. W. D. Paton, Br. J. Pharmac. Chemother. 12, 119 (1957).

3. K. Jhamandas, J. W. Phillis and C. Pinsky, Br. J. Pharmac. Chemother. 43, 53 (1971).

4. G. M. Lees, H. W. Kosterlitz and A. A. Waterfield, in Agonist and Antagonist Actions of Narcotic Analgesic Drugs (Eds. H. W. Kosterlitz, H. O. J. Collier and J. E. Villarreal), p. 142. MacMillan, London (1972).

5. E. F. Domino and A. E. Wilson, J. Pharmac. exp. Ther. 184, 18 (1973).

6. D. L. Cheney and I. Hanin, Fedn Proc. 32, 757 (1973).

7. E. F. Domino, M. E. Mohrman, A. E. Wilson and V. B. Haarstad, Neuropharmacology 12, 549 (1973).

8. P. I. A. Szilagyi, J. P. Green, O. M. Brown and S. J. Margolis, J. Neurochem. 19, 2555 (1972). 